\title{
PERSONALIZATION OF INSTRUCTION IN ELECTRONIC LEARNING ENVIRONMENT
}

\section{Blanka CZECZOTKOVÁ - Kateřina KOSTOLÁNYOVÁ}

\begin{abstract}
Information and communication technologies are integral part of today's modern instruction. However, we must point out that the potential of computer and internet based support is not yet being fully exercised. Each student is an individual in the process of education, and therefore should be accordingly provided with "tailored" curriculum. E-learning and educational materials need to be adjusted and designed in such a way to ensure that students would be able to work optimally and master the curriculum given with the highest efficiency. In this paper we briefly describe the whole project dealing with the problematic of "the efficient way of learning" and the most suitable individual teaching methods and teaching styles in electronic education.
\end{abstract}

Key words: student, educational material, virtual teacher, teaching method, teaching style.

\section{PERSONALIZACE VÝUKY V ELEKTRONICKÉM PROSTŘEDÍ}

Resumé: Informační a komunikační technologie jsou již nedílnou součástí dnešní moderní výuky. Musíme ale podotknout, že možnosti podpory počítačủ a internetu nejsou ještě zcela ve výuce plně využity. Každý student je $\mathrm{v}$ procesu vzdělávání individualita, a proto by mu měla být podávána studijní látka př́mo na míru. E-learning a studijní materiály je třeba zpracovat tak, aby s nimi student dovedl optimálně pracovat a zvládl se učivo naučit co nejefektivněji. V tomto článku se stručně zmíníme o celém projektu, zabývající se problematikou „efektivnějšího způsobu učení“ a o nejvhodnějších individuálních vyučovacích metodách a vyučovacích stylech pro elektronické vzdělávání.

Klíčová slova: student, studijní materiál, virtuální učitel, vyučovací metoda, vyučovací styl.

\section{1 Úvod}

Vrat'me se o pár let zpátky a zavzpomínejme si na svá školní léta. Vzorně jsme seděli v lavicích a pečlivě sledovali výklad učiva, jež nám prednáší učitel. Jednu chvílí se nám zdála látka triviální, jindy bychom potřebovali mnohem podrobnější výklad učiva. At' už to bylo tak či onak, většina $z$ nás si téměř jistě položila nejednou otázku ,jak se danou látku nejlépe naučit".

Odpovědět si na výše uvedenou otázku není vůbec primitivní, jak se zprvu jeví. Z mnoha důvodu, nelze vytvořit jediný postup učení se, dle něhož by se dala daná látka naučit. Podstatným důvodem je fakt, že každý jedinec se rozvíjí jinak, má různé zvyky a styly učení, preferuje při studiu různé podmínky, použivá jiné taktiky učení a také má vrozené jiné smyslové vnímání.

VČeské republice je již třetím rokem realizován projekt „Adaptivní individualizovaná výuka ve-learningu“, jehož náplní je nalézt na výše položenou otázku odpověd'. Hledá tedy vhodná východiska a podmínky, přizpůsobuje studijní prostředí pro rozličné typy studentů. Před zahájením výuky, student vyplní dotazník, pomocí něhož se zjistí jeho učební styl. Následně je mu přiřazen „virtuálním učitelem“ výukový styl, kterým je student po dobu výuky veden a také vyučovací metoda, která bude studentovi dle jeho charakteristických vlastností vyhovovat co nejlépe.

Úkolem je předložit učivo šité přímo na míru jednotlivým studentům. Studentovi bude předloženo takové učivo, ze kterého se naučí dovednosti a znalosti co nejlépe a v co nejefektivnějším čase.

Tento př́spěvek se skládá z šesti kapitol. Ve druhé kapitole jsou definovány charakteristické vlastnosti studenta. Třetí kapitola je věnována struktuře a tvorbě studijní opory. Vyučovací metody a jejich klasifikace jsou popsány $\mathrm{v}$ kapitole čtvrté. Kapitola pátá se zabývá vyučovacími styly učitelů a v poslední šesté kapitole je naznačeno, jak lze dané vyučovací metody a vlastnosti vyučovacích stylů vhodně asociovat $\mathrm{k}$ vlastnostem učebních stylů studentů. 
2 Vlastnosti studentů ovlivňující jeho učební styl

$\mathrm{Na}$ počátku projektu bylo nutné nalézt charakteristické vlastnosti jednotlivých studentů, které ovlivňují jeho učební styl [5]. Po pečlivě vytvořené analýze byla definována množina charakteristických vlastností studenta, které ovlivňují jeho učební styl. Pro zjištění učebního stylu studenta, byl pedagogy a psychology vytvořen vhodný dotazník, vycházející $\mathrm{z}$ charakteristických vlastností studentů.

Charakteristické vlastností studentů jsou rozděleny do 5 skupin. Viz následující tabulka 1.

\begin{tabular}{|l|l|}
\hline \multicolumn{2}{|c|}{ Vlastností studentů } \\
\hline $\begin{array}{l}\text { Smyslové } \\
\text { vnímání }\end{array}$ & $\begin{array}{l}\text { Vizuální } \\
\text { Auditivní } \\
\text { Verbální } \\
\text { Kinestetický }\end{array}$ \\
\hline $\begin{array}{l}\text { Sociální } \\
\text { aspekty }\end{array}$ & $\begin{array}{l}\text { Sám } \\
\text { Ve dvojici } \\
\text { S učitelem } \\
\text { Ve skupině }\end{array}$ \\
\hline $\begin{array}{l}\text { Afektivní } \\
\text { aspekty }\end{array}$ & $\begin{array}{l}\text { Vnitřní motivace } \\
\text { Vnější motivace }\end{array}$ \\
\hline Taktiky učení & $\begin{array}{l}\text { Systematičnost } \\
\text { Způsob teor-exper } \\
\text { Postup detail-holis } \\
\text { Pojetí hloub-povrch }\end{array}$ \\
\hline Autoregulace & Schopnost regulace učiva \\
\hline
\end{tabular}

Tabulka 1: Vlastností studentì

\section{Popis skupin vlastností studentů}

Skupina smyslového vnímání se skládá z vizuálního typu, který preferuje obrázky, tabulky, grafy a schémata. Kontakt s jinými lidmi a mluvené slovo jsou charakteristickými vlastnostmi studentů, kteří spadající do auditivního typu. Kinestetický typ upřednostňuje názorné modely, ukázky a praktické informace. Posledním typem je typ verbální, který je zaměřen na textovou formu informací.

Sociální aspekty se zabývají tím, jaká společnost studentovi při studiu vyhovuje nejlépe.

Třetí typ afektivní aspekty se zaměřují na postoj a city studenta, které ovlivňují průběh studentova učení. Vnitřní motivace k učení je charakteristická tím, do jaké míry se sám samotný student motivuje, mezi vnější motivaci patř́i např́klad pracovní požadavky, rodiče atd.

Taktiky učení popisují způsob a průběh učení studenta. Systematičnost učení studenta popisuje pořadí učení studenta, které může probíhat postupně - logicky na sebe navazující kroky nebo téměř náhodně - bez spojitostí.

Způsob učení členíme na teoretické odvozování a na taktiku experimentování. Postup učení rozdělujeme na detailistickou a holistickou taktiku. Pojetí učení studenta dělíme na hloubkové, strategické a povrchové.

Autoregulace nám vytyčuje do jaké míry je student schopen samostatně regulovat své učení. [5]

\section{Tvorba studijních materiálů pro personalizovaný e-learning}

Když už víme, jaký učební styl student preferuje, pokusíme se přiřadit mu vhodný studijní materiál. Můžeme si položit otázku, jak nejlépe vytvořit studijní materiály pro studenta, tak aby mu byly šité přímo na míru“.

K. Kostolányová [6] rozdělila studijní materiál na elementární části. Tyto části se tvoří ve vícenásobných variantách:

- varianty dle formy výkladu - pro jednotlivé typy smyslového vnímání,

- varianty dle hloubky výkladu - pro různou míru podrobnosti výkladu učiva.

Každý autor by měl dodržet následující zásady:

- vytvořit studijní materiál pro každou smyslovou variantu

- pro jednotlivé smyslové varianty vytvořit studijní materiál v různých hloubkách výkladu.

\section{Vyučovací metody}

Pod pojmem vyučovací metoda můžeme rozumět cestu studenta učivem, která je utříděna vhodným postupem tak, aby student dospěl $\mathrm{k}$ vymezeným cílům - znalostem a dovednostem.

Metodu výuky J. Maňák charakterizoval jako ,jako koordinovaný systém vyučovacich činností učitele a učebnich aktivit žáků, který je zaměren na dosažení výchovně vzdělávacích cílü“ [8].

Podle O. Kádnera je ,metoda je plánovitý a promyšlený postup výchovy nebo vyučováni" [10].

Existuje řada odborníků, kteří se zabývali vyučovacími metodami a vytvořili různá hlediska jejich dělení. Mezi nejčastěji uváděná hlediska patří - hledisko psychologické, procesuální, hledisko fáze výuky, hledisko logické, organizační a hledisko dle charakteru zdroje informací. V současné době si na své přicházejí tzv. aktivizační metody, mezi něž zahrnujeme diskuse, výukové hry, projektovou metodu, metodu zkušenostního učení a jiné. 
Po důkladné analýze vyučovacích metod, jsme upustili od duplicitních kriteriálních dělení - např. rozdělení E. Stračára, D. O. Lordkipanidze, S. Vrány, Z. Peška, J. Maňák a dalších, kteří se zabývali rozdělením výukových metod dle charakteru zdroje informací.

Po odstranění stejných nebo velice si podobných metod, jsme vytvořili hledisko, které vycházelo z J. Maňáka, jež bylo nejvíce diferencované. K jednotlivým metodám jsou navíc doplněny další formy dělení, které uvádějí jiní autoři.

\begin{tabular}{|c|c|}
\hline \multicolumn{2}{|r|}{ Vyučovací metody } \\
\hline \multirow{13}{*}{$\begin{array}{l}\text { Slovni } \\
\text { metody }\end{array}$} & přednáška (studie, pojednání) \\
\hline & vysvětlování \\
\hline & vyprávění (příběh) \\
\hline & četba literatury \\
\hline & referát \\
\hline & instruktáž \\
\hline & $\begin{array}{l}\text { rozhovor (debata, diskuse, } \\
\text { konverzace, rozmluva) }\end{array}$ \\
\hline & beseda \\
\hline & dramatizace \\
\hline & seminární práce \\
\hline & práce $\mathrm{s}$ textem \\
\hline & písemné cvičení \\
\hline & kompozice \\
\hline$\cdots$ & $\cdots$ \\
\hline
\end{tabular}

Tabulka 2: Rozdělení vyučovací metod

\section{Vyučovací styly}

I zde existuje řada odborníků, zabývajícími se vyučovacími styly učitelů. Mezi nejznámější odborníky bezprostředně jistě patří K. Lewin, R. Lippit a R. K. White, C. G. Jung, G. D. Fenstermacher, J. F. Soltis, E. Luk, J. Režný, T. Leary, W. O., Ch. Casselmannovo a mnoho dalších.

Podobně jako u vyučovacích metod, jsme vytvořili seznam všech vyučovacích stylů učitelů a přiřadili jim vhodné vyučovací styly učitelů, které jsou použitelné pro elektronické vzdělávání.

V následující tabulce je uvedena část vyučovacích stylů a jejich základní charakteristika. [1]

\begin{tabular}{|c|c|}
\hline \multicolumn{2}{|c|}{ Vyučovací styly učitelů } \\
\hline \multirow{7}{*}{$\begin{array}{c}\text { Autokratický } \\
\text { styl }\end{array}$} & předkládá úkoly \\
\hline & udílí rozkazy, př́íkazy \\
\hline & $\begin{array}{l}\text { určuje způsob cesty } \mathrm{k} \\
\text { výsledkům }\end{array}$ \\
\hline & útlum osobnosti \\
\hline & stereotypní výuka \\
\hline & \begin{tabular}{|l} 
přesné plnění úkolů, \\
kontrola studentů
\end{tabular} \\
\hline & logická struktura učiva \\
\hline \multirow{3}{*}{$\begin{array}{c}\text { Demokratický } \\
\text { styl }\end{array}$} & samostatnost studentů \\
\hline & studenti debatují, diskutuji \\
\hline & rozvoj osobnosti \\
\hline \multirow{4}{*}{$\begin{array}{c}\text { Vědecko- } \\
\text { systematický } \\
\text { styl }\end{array}$} & systematičnost \\
\hline & $\begin{array}{l}\text { vyvozování logických } \\
\text { závěrů }\end{array}$ \\
\hline & vede $\mathrm{k}$ logickému myšlení \\
\hline & $\begin{array}{l}\text { systém teoretických } \\
\text { poznatků }\end{array}$ \\
\hline \multirow{3}{*}{ Praktický styl } & organizuje práci studentů \\
\hline & spojuje teorií s praxí \\
\hline & rozvíjí praktické myšlení \\
\hline ... & $\ldots$ \\
\hline
\end{tabular}

Tabulka 3: Vyučovací styly a jejich rozdělení

\section{Přiřazovací pravidla}

Z výše uvedeného vyplývá, že existuje velké množství klasifikací, hledisek a typů jak vyučovacích metod, tak vyučovacích stylů učitelů.

Po výběru výukových metod a výukových stylů uplatnitelných v e-learningu je nyní naším úkolem rozhodnout, které vyučovací metody a vyučovací styly jsou optimální pro jednotlivé studenty. Známe, charakteristické vlastnosti ovlivňující učební styl studenta na straně jedné a známe seznam vyučovacích metod a seznam vyučovacích stylů na straně druhé. Pro přiřazování optimálních vyučovacích nástrojů individualitám studentů aplikujeme pravidla typu vlastnost studujícího $=\mathrm{ABC} \Rightarrow$ výuková metoda $=$ XYZ \& styl výuky $=$ UVW prrípadně dílčí pravidla

$$
\begin{gathered}
\text { vlastnost studujícího }=\mathrm{ABC}=>\text { výuková } \\
\text { metoda }=\mathrm{XYZ} \\
\text { vlastnost studujícího }=\mathrm{ABC}=>\text { styl výuky }=
\end{gathered}
$$
UVW 
Tedy, má-li student vlastnost $\mathrm{ABC}$, pak aplikujeme vyučovací metodu XYZ a styl řízení výuky UVW.

Na základě analýz byl navržen komplex pravidel, reflektující všechny charakteristiky učebního stylu. Danému studentovi jsou pak vybrána všechna pravidla, odpovídající všem jeho charakteristickým rysům. Z nich je sestaven individuální výukový postup, optimalizovaný na míru studentovi.

Tento postup realizuje tzv. virtuální učitel výukový program, zabudovaný do adaptivního LMS. Virtuální učitel přidělí učebnímu stylu studenta vhodnou metodu výuky a výukový styl.

Př́klady pedagogických pravidel

1. Má-li student způsob pojetí výuky od praxe $\mathrm{k}$ teorii, pak se mu přiřadí z názorných metod - demonstrace a předvádění - pokusy, činnosti a ze slovních metod přednáška, vysvětlování, jako výukový styl se zvolí styl praktický.

od praxe $\mathbf{k}$ teorii $=>$ metoda $=$ názorná, slovní \& styl = praktický

2. Vyžaduje-li student při učení se obrázky, tabulky a grafy, pak se mu přiřadí z názorných metod - pozorování - obrazi̊, dokumentů a filmů.

\section{forma $=$ vizuální $=>$ metoda $=$ názorná}

3. Vyžaduje-li student při učení se kontakt s lidmi, pak se mu přiřadí ze slovních metod přednáška, vysvětlování, vyprávění, instruktáž, rozhovor.

forma $=$ auditivní $=>$ metoda $=$ slovní

4. Vyžaduje-li student volnost při učení, pak jako výukový styl se přiřadí styl demokratický.

volnost při učení $=>$ styl $=$ demokratický

5. Vyžaduje-li student textovou formu, pak se mu přiřadí ze slovních metod práce s textem.

$$
\text { forma }=\text { verbální }=>\text { metoda }=\text { slovní }
$$

Předností tohoto př́stupu je to, že pedagog expert, zadávající pravidla pro řízení výuky, má k dispozici kompletní škálu vyučovacích metod i vyučovacích stylů. Nepoužívá tedy jen své obvyklé metody, ale je inspirován i metodami jiných odborníků. Může tak spolehlivěji a úplněji definovat ř́dicí pravidla. [1]

\section{Závěr}

Cílem článku byla analýza existujících vyučovacích metod, vyučovacích stylů a jejich optimální selekce pro rozdílné typy studentů.
Po zmapování všech vyučovacích metod jsme eliminovali ty vyučovací metody, které jsou totožné anebo jsou si velmi podobné. U vyučovacích stylů učitelů jsme také sjednotili obdobné vlastnosti vyučovacích stylů.

Výsledkem je řada pravidel, přiřazujících konkrétnímu studentovi optimální výukový styl. Pravidla jsou základem pro konstrukci řady algoritmů tzv. virtuálního učitele.

Tento článek vznikl za podpory projektu ESF OP VK číslo CZ.1.07/2.3.00/09.0019 s názvem „Adaptivní individualizovaná výuka v e-learningu“".

\section{Literatura}

[1] CZECZOTKOVÁ B. Individuální výukové styly ve-learningu. Information and Communication Technology in Education. Ostrava: Ostravská univerzita, 2011. ISBN 97880-7368-980-3.

[2] FENSTERMACHER, G. D., SOLTIS, J. F. Vyučovací styly učitelů. Praha : Portál, s. r. o., 2008 ISBN: 978-80-7367-471 7;

[3] GAGNÉ, R. M. Podmínky učení. Praha : SPN, 1975. 287s.

[4] GRASHA, A. F. Teaching with Style [online]. Dostupný z WWW: http://ilte.ius.edu/pdf/teaching_with_style.pdf

[5] KOSTOLÁNYOVÁ, K., ŠARMANOVÁ, J., TAKÁCS, O. Adaptable educational supports. Information and Communication Technology in Education. Ostrava: Ostravská univerzita, 2010. s. 117-121. ISBN 978-80-7368-775-5.

[6] KOSTOLÁNYOVÁ, K., ŠARMANOVÁ, J., TAKÁCS, O. Classification of Learning Styles for Adaptive Education. The New Educational Review. 2011, roč. 2011, sv. 23, s. 199-212.

[7] MAREŠ, J. Styly učení žáků a studentů. Praha : Portál, 1998. 240 s. ISBN 80-7178-246-7. [8] MAŇÁK, J. Nárys didaktiky. Brno : rektorát Masarykovy univerzity Brno,1991. 113 s. ISBN 80-210-0210-7.

[9] MAŇÁK, J.; ŠVEC, V. Výukové metody. Brno : Paido, 2003. ISBN 80-7315-039-5.

[10] VRÁNA, S. Učebné metody. Brno : Pokrok, 1938. $249 \mathrm{~s}$.

\section{Mgr. Blanka Czeczotková \\ Katedra informačních a komunikačních technologií, Pedagogická fakulta OU \\ Fr. Šrámka 3 \\ 70903 Ostrava - Mar. Hory \\ Tel: +420 775153267 \\ E-mail: d09434@student.osu.cz \\ Www pracovisko: http://pdf.osu.cz/kik/}

